\title{
A Study on the Cultivation of Non-English Majors' Autonomous Learning Ability of Listening Based on Metacognitive Theory
}

\author{
Lei Liu ${ }^{1, a^{*}}$ \\ ${ }^{1}$ Foreign Language Department in Qiqihar Medical University, Qiqihar 161006, \\ HeiLongjiang, China \\ a84056867@qq.com
}

\begin{abstract}
Keywords: Metacognitive theory and strategy; English listening; Autonomous learning ability
\end{abstract}
\begin{abstract}
Education in the 21 st century is a modern education. Its main goal is to cultivate students' autonomous learning ability. Only by studying independently can we really master the skills and meet the needs of the development of the times. The current teaching mode of college English listening comprehension is generally cramming teaching, which leads to weak students' English listening ability and poor language ability. This paper explores the close relationship between metacognitive strategies and English listening comprehension. Through the experience of English listening teaching and self-training, combined with metacognitive strategy theory, this paper studies the cultivation of non-English majors' autonomous learning ability of listening, which helps English listening teaching .
\end{abstract}

\section{Introduction}

In English learning, language information is mainly spread by sound. In understanding the acquisition of information, memory and second language proficiency, "listening" is crucial and occupies a very important position. In order to improve students' communicative competence in English, we must first improve their listening skills. In the traditional English teaching mode, teachers dominate, students rely on teachers and access to knowledge blindly and rigidly, and the learning effect is not satisfactory. "Autonomous learning" is based on the development of self-awareness of "can learn", based on students with intrinsic learning motivation of "want to learn", based on the students who master a certain learning strategy of "will learn", and based on the willpower efforts of "insist on learning". To do anything, we should pay attention to strategies, and English learning is no exception. Using effective English learning strategies can not only improve English learning methods, improve learning outcomes and qualities, but also ease learning burdens.

\section{The Theoretical Significance of Metacognitive Strategy}

The concept of metacognition, proposed by the famous American psychologist Flavell, refers to the cognition and monitoring that a person has about his thinking activities and learning activities. He believes that the concept of metacognition includes the individual's own cognitive processes, the results and the knowledge of any related affairs and the individual's active monitoring and coordination of cognitive processes and the adjustment of cognitive outcomes. Popularly, metacognition is about cognition. Since then, many scholars have explored and studied the theory of metacognition deeply and introduced it into the concept of learning strategy, which is called metacognitive strategy. Metacognitive strategy is to help students learn "how to learn" so that students become the leader of learning.

\section{Traditional Teaching Status Quo}

The result of traditional English teaching is that students have poor listening skills. On one hand, teaching attaches great importance to reading and other visual input type content, and ignores auditory input type content. On the other hand, students lack targeted strategy guidance and training 
while studying. At present, there are many problems in college English listening teaching at present stage: most English teachers still adopt the traditional mode of "cramming", while teachers and students, students and students have less interaction in the classroom. Listening class teachers play listening materials and students answer, which is a solidified mode. Teachers play a limited capacity for listening information, causing students to absorb a small amount of information in English. This kind of listening class which includes much listening and less speaking, to be precise, it should be called listening and speaking class. In the actual listening teaching, "listening" takes too much time, leaving little or no time for the students. Learning efficiency is low, students can not concentrate on learning, and also can not be interested in it. After listening class, in addition to completing the task assigned to teachers, students rarely develop their own listening program. Such problems seriously hamper the improvement of students' English listening ability, which is not conducive to the development of students' English qualities.

In recent years, a series of reforms have been carried out in CET4 and CET6 in our country. The proportion of listening comprehension has risen from $20 \%$ to $35 \%$, and has also been improved in speech rate, vocabulary and difficulty. All these reforms put forward higher requirements for English listening teaching. On the other hand, the rapid development of network technology provides colleges and universities a large number of rich resources for English teaching, and helps higher institutions to open up and create a variety of practice and application ways for teaching reforms. In 2007, the "College English Curriculum Requirements" issued by the Ministry of Education especially emphasized that colleges and universities should explore the establishment of a listening teaching mode with Internet technical support according to the English level of their students and their own conditions so that students and teachers can directly use the campus network or LAN for listening teaching and training. College English listening teaching is no longer limited to the traditional classroom, but also to promote students to use extra-curricular time to enhance the level of listening reasonably and efficiently.

\section{Application of Metacognitive Strategies in English Listening Teaching}

To sum up, metacognitive strategies play an important role in improving students' English listening ability. Metacognitive strategies are fully utilized in the process of listening learning, and students are trained in this respect, which can improve students' listening ability and autonomous learning ability. This will require teachers to first help students to establish metacognitive awareness, and recognize the importance of metacognitive strategies for listening learning. Second, teachers should reveal to students the essence of listening, effective listening process and purpose to help students establish learning strategies and goals, so that students can apply the strategy to actual listening material, and change "passive learning" to "active learning". Based on the practical experience of English teaching and listening training and self-strategy training experience, combined with metacognitive strategy theory, the following five metacognitive strategies will be presented.

Activation. Activation is an advance preparation strategy in metacognitive strategies. Teachers assist students in establishing learning goals and making learning plans according to their individual conditions, and these things are done specifically in the pre listening stage of listening teaching. As the name implies, teachers should do some work to activate long-term memory of students before releasing, such as listening to the full-text introduction or related pictures, stories and thematic information, so as to reduce the blindness in students' listening and improve their predictive ability.

Clarification. Clarification also belongs to the metacognitive strategy in advance preparation strategy. It reminds students to pay attention to listening materials, capture important information, and promptly deal with and remedy the missing part of the process of hearing. The ability of the human brain to process information is limited and it is impossible to write down what is heard accurately and therefore the information must be screened. What teachers need to do is to help students improve their understanding of listening tasks and let students know clearly that the purpose of listening comprehension is to understand the essays and grasp the theme and help students to avoid tension and anxiety caused by fear of listening. This is an important part of metacognitive strategy training. 
Maintenance. Maintenance is a self-management strategy in metacognitive strategy. After the sound enters the auditory storage phase, it is followed by the short-term memory processing information phase. Short-term memory refers to the memory that keeps information within one minute, and it is operational. Each piece of information stays in mind for only a moment, freeing up space for the influx of hearing material, and the processing of information-processing activity depends on the capacity of our short-term memories. Therefore, the third strategy has two meanings: one is to maintain awareness of the task of listening; the other is to maintain short-term memory efficiency.

Transferring Mode. Transferring mode belongs to self-management strategy in metacognitive strategy. Modality refers to the way humans interact with the external environment through their senses. The single modality interacts by a single sense, the dual modality interacts by two senses, and the multimodality interacts by three or more senses. Traditional listening teaching only relies on listening to obtain information, and now we can guide students to carry out multimodal listening training, for example, we can let the students repeat the relevant content after listening to the recording, or list the article framework. This process of learning from the input auditory modality into voice organ movement mode and writing mode achieves the transfer mode. This not only strengthens students' internalization of what they listen to, but also improves their oral communication skills.

Extension. Extension strategy belongs to self-evaluation strategy in cognitive strategy. It is so-called that "learn without thinking is indiscreet, thinking and not learning is perilous". Teachers guide students to self-test and self-assessment. During the learning process, teachers give timely feedback on learning activities, adjust their own strategies to help students get close to their learning goals, promote the internalization of learning strategies, achieve the migration and extension of learning strategies, and cultivate students' autonomous learning ability which is based on metacognitive characteristics. The effect of learning knowledge without thinking is discounted. Any so-called good learning strategy is only effective on suitable learners. Otherwise, it is necessary to adjust in time to explore other ways, which is the process of self evaluation and adjustment. Of course, evaluation can also be carried out among teams, among peers, between teachers and students, so that successful learning strategies can be continuously improved and extended in various learning and communication processes.

\section{Conclusion}

Due to the complexity of language learning and the limitation of environmental conditions, English listening has long been a source of deep distress to many English learners and teachers in our country. Facts have shown that most students accustomed to intense and rigid learning styles can not adapt to professional English learning. Therefore, it is imminent to teach the students how to learn. Through the guidance of metacognitive strategy theory, this paper explores the strategies of activating, clarifying, maintaining, transforming and extending English listening teaching so that students can consciously improve their autonomous learning ability and dominate and manage their learning time as masters of learning. Metacognitive theory is a necessary and effective way to improve students' listening ability. Wenden pointed out that the introduction of metacognitive knowledge into listening training helps to achieve more effective listening and cognitive effects. With the enrichment of learners' listening practice, their cognitive awareness of metacognition will also be developed accordingly. The development of metacognitive awareness in turn can coordinate and control the learner's cognitive process of hearing to help them find the best way to practice and consolidate what they have learned to promote their listening skills. Metacognitive awareness and listening ability complement each other, and both rely on the independent practice of cognitive subjects to enrich and develop. 


\section{Acknowledgements}

Qiqihar philosophy and social science research planning project. Project number:QSX2014-31QN. Project name:The analysis of the application of multimedia in Qiqihar primary and secondary school.

\section{References}

[1] X.D.Ding and Q.Dou: A Study of the Relationship between Metacognitive Strategies and College English Autonomous Learning Ability[C], The Conference Proceedings of the Third Forum on the Development of Philosophy and Social Sciences in National Agroforestry Colleges and Universities, 2012:376-378.(In Chinese)

[2] H.Yu and Q.E.Xie: An Investigation and Analysis of the Current Situation of English Listening Learning for non English Majors in Local Colleges and Universities[J], Journal of Inner Mongolia Agricultural University(Social Science Edition), 2012(1).(In Chinese)

[3] C.H.Yu: The Theory Construction of RT-SL: Second Language Acquisition Study from the Pragmatic Perspective[J], Contemporary Foreign Language Studies, 2013a, (4):21-26.(In Chinese)

[4] J.F.Wang and J.Y.Li: Metacognitive Learning Strategies and the Improvement of Autonomous Learning Ability in Listening[J], Journal of Tianjin Manager College, 2012(12).(In Chinese)

[5] H.Shi and W.W.Fan: A Study on College Students' Listening Anxiety under the Condition of Compound Dictation of CET-4[J], Journal of PLA University of Foreign Language, 2013, (6):55-60.(In Chinese)

[6] L.H.Tan: Chinese EFL learner' Use of Cohesive Devices in Performing Listening Comprehension Tasks: An Empirical Study[J], Modern Foreign Languages, 2010(4):85-92.(In Chinese)

[7] T.Chen: The Current Situation and Countermeasures of College English Listening Autonomous Learning -- Taking Zhanjiang Normal University as an example[J], Journal of Hunan University of Science and Engineering, 2010,(7).(In Chinese)

[8] P.Y.Ji and M.Y.He: A Study of Listening Strategies for College English Teachers and Students[J], Foreign Language World, 2004(5).(In Chinese)

[9] J.D.Yang: Metacognitive Strategy Training in Listening Teaching[J], Foreign Language Education, 2003,(4).(In Chinese)

[10]Q.F.Wen: On English Learning Strategies[M], Shanghai: Shanghai Foreign Language Education Press, 1996.(In Chinese)

[11]C.Cheng and H.Zhou: The Application and Effective Analysis of Metacognitive Strategies in English Listening Learning[J], Heilongjiang Institute of Education, 2007(12).(In Chinese)

[12] G.X.Xiong: The Influence of Metacognitive Strategies on the Listening Comprehension of Guizhou English Majors[J], Journal of Jiamusi Education Institute, 2010(5).(In Chinese)

\section{Corresponding author}

Lei Liu, Master degree candidate. Work in Foreign Language Department in Qiqihar Medical University, Qiqihar, Heilongjiang, 161006. Major: Foreign linguistics and applied linguistics 